\title{
An improved method for counting bacteria from sediments and turbid environments by epifluorescence microscopy
}

\author{
Mirko Lunau, ${ }^{*}$ Andreas Lemke, Katja Walther, \\ Willm Martens-Habbena and Meinhard Simon \\ Institute for Chemistry and Biology of the Marine \\ Environment, University of Oldenburg, D-26111 \\ Oldenburg, Germany.
}

\section{Summary}

We present a new procedure for effectively detaching particle-associated bacteria by $10 \%(\mathrm{v} / \mathrm{v})$ methanol and sonication which is particularly suitable for samples with a high particle load and sediments. We also optimized the sample preparation by applying the highly dsDNA-specific fluorescent stain SybrGreen I together with an optically brilliant mounting medium (polyvinylalcohol 4-88, 'moviol') in one step. The new protocol allows a much faster, easy and less toxic handling of samples as compared to other methods. Cells are stained directly on a black Nuclepore filter and show an intensive fluorescence signal with low background. The detachment procedure was optimized with respect to the temperature of the $10 \%$ methanol solution $\left(35^{\circ} \mathrm{C}\right)$, ultrasonication and centrifugation. The application of the new method in comparison with detachment procedures with pyrophosphate and Tween- 80 with various types of marine samples including sediments always yielded higher numbers and/or higher fractions of particle-associated cells. Staining and mounting the samples with the moviol-SybrGreen I solution allowed an accurate and highly reproduceable enumeration of bacteria also in samples with high concentrations of SPM. Fixation of bacteria by glutardialdehyde resulted in a brighter fluorescence as compared to fixation by formalin. Because of the high specificity to dsDNA and bright fluorescence of SybrGreen I, the fast and easy handling and the possibility to store stained samples for at least several months at $-20^{\circ} \mathrm{C}$ without any loss in fluorescence intensity, the newly developed method is also an attractive alternative to DAPI staining of aquatic bacteria.

Received 20 July, 2004; accepted 23 November, 2004. *For correspondence. E-mail lunau@icbm.de; Tel. +49 441798 3416; Fax +494417983438.

\author{
Introduction
}

Since the introduction of Nuclepore filters and staining by acridine orange [3,6-bis(dimethylamino)acridinium chloride] and DAPI (4',6-diamidino-2-phenylindole) more than 24 years ago epifluorescence microscopy has become the standard procedure to enumerate bacteria in aquatic systems and other environmental samples (Zimmermann and Meyer-Reil, 1974; Hobbie et al., 1977; Porter and Feig, 1980; Kepner and Pratt, 1994). This method has proven very useful and reliable in many applications in which bacteria can be properly stained and distinguished from the background and be evenly distributed on the filter. Some applications provided difficulties and required modifications, because of unspecific staining and autofluorescence of other components in the samples, such as humic matter, other colloids and inorganic and organic particles. Rapid fading of DAPI-stained cells in particular of marine samples may also bias the results (Wilson et al., 1990). Another problem concerns samples with high amounts of particle- and surface-associated bacteria, because these bacteria are unevenly distributed and a certain fraction may be obscured by opaque particles and escape enumeration. Several methodological improvements were introduced to obtain better results, mainly trying to reduce background fluorescence and to detach bacteria from particles. Acridine orange counterstaining was successfully applied to estuarine particle-associated bacteria (Crump et al., 1998). Other methods detached bacteria from particles and surfaces by adding pyrophosphate or Tween-80 as detergent, followed by ultrasonication, homogenization or centrifugation (Bakken, 1985; Velji and Albright, 1986; Yoon and Rosson, 1990; Buesing and Gessner, 2002). Enzymatic treatment was introduced as another successful means to remove bacteria from their organic matrix (Böckelmann et al., 2003). A step forward was the introduction of more specific stains, such as acriflavine for humic-rich samples (Bergström et al., 1986) and more recently SybrGreen I, as highly specific and very intense fluorescent stains, which are highly specific for dsDNA and also enable the enumeration of viruses (Noble and Fuhrman, 1998; Weinbauer et al., 1998; Danovaro et al., 2001).

So far, it appears that a successful application of a detachment procedure remains rather sample-specific 


\section{M. Lunau et al.}

and no method exists which provides a procedure for a general use in various fields, including biofilms, organic aggregates and sediments.

Therefore, we developed a new method which includes the reliable detachment of bacteria from the organic matrix of particles by methanol, centrifugation and staining the bacteria by SybrGreen I. The staining procedure includes mounting and fixing the sample by a solution of polyvinylalcohol (moviol). The new procedure allows an effective, unspecific detachment, a rapid and very specific staining of bacteria in samples from the water column, organic and inorganic aggregates, and from the sediment by very low amounts of stain. The application of SybrGreen I much reduces the hazard of preparing samples for epifluorescence microscopy because this stain is not classified as hazardous and much less mutagenic than ethidium bromide (Singer et al., 1999).

\section{Results and discussion}

We tested the new detachment and staining procedure (Fig. 1) with a wide range of samples from different stations (Table 1) and two bacterial isolates. There was no significant difference (one way ANOVA, Table 2) in the abundance neither of the two isolates nor the sample from the German Bight by staining with either SybrGreen I, or DAPI or acridine orange. In contrast, the Wadden Sea sample stained by SybrGreen I yielded a significantly lower number than stained by DAPI or acridine orange (Table 3). We attribute this difference in the latter sample with high concentrations of SPM to the fact that DAPI as well as acridine orange stained unspecifically other particles than bacteria or bacterial cells without dsDNA, which were also counted after staining by these dyes, but not after staining with the highly dsDNA-specific SybrGreen I. Hence, these tests show that in samples without interfering SPM all three dyes yield similar numbers but that SybrGreen I staining yields more reliable results in samples with high amounts of SPM as its high specificity is due to dsDNA.

\section{Detachment procedure}

The critical steps of the new detachment procedure were tested with two samples from the German Wadden Sea. These samples collected in February and August 2003 differ in aggregate structure and composition (Table 4). Centrifugation exceeding $190 \mathrm{~g}$ and $1 \mathrm{~min}$ resulted in significant losses of cell numbers (Fig. 2A). The addition of $10 \%$ methanol to the sample without any ultrasonic treatment already increased cell numbers by $6.2 \%$ and $22.5 \%$ as compared to a control without methanol in the February and August samples respectively (Fig. 2B). The highest increases in cell numbers of $114 \%$ and $54.1 \%$ in the
February and August samples, respectively, were reached after 15 min of ultrasonication. Thirty minutes of ultrasonication resulted in lower increments, presumably because of cell damage. Heating the sample during the methanol treatment to $35^{\circ} \mathrm{C}$ enhanced the cell yield by $12.5 \%$ and $25.6 \%$ in the February and August samples respectively (Fig. $2 \mathrm{C}$ ). Heating to $50^{\circ} \mathrm{C}$ resulted in lower cell numbers in the August sample, and in the February sample even led to reduced cell numbers as compared to an untreated control. This temperature presumably already led to cell disintegration or melting of the dsDNA of some bacteria thus reducing the specific binding of SybrGreen I. Vortexing the samples after ultrasonication led to reduced cell numbers (Fig. 2D). Because of the high load of inorganic

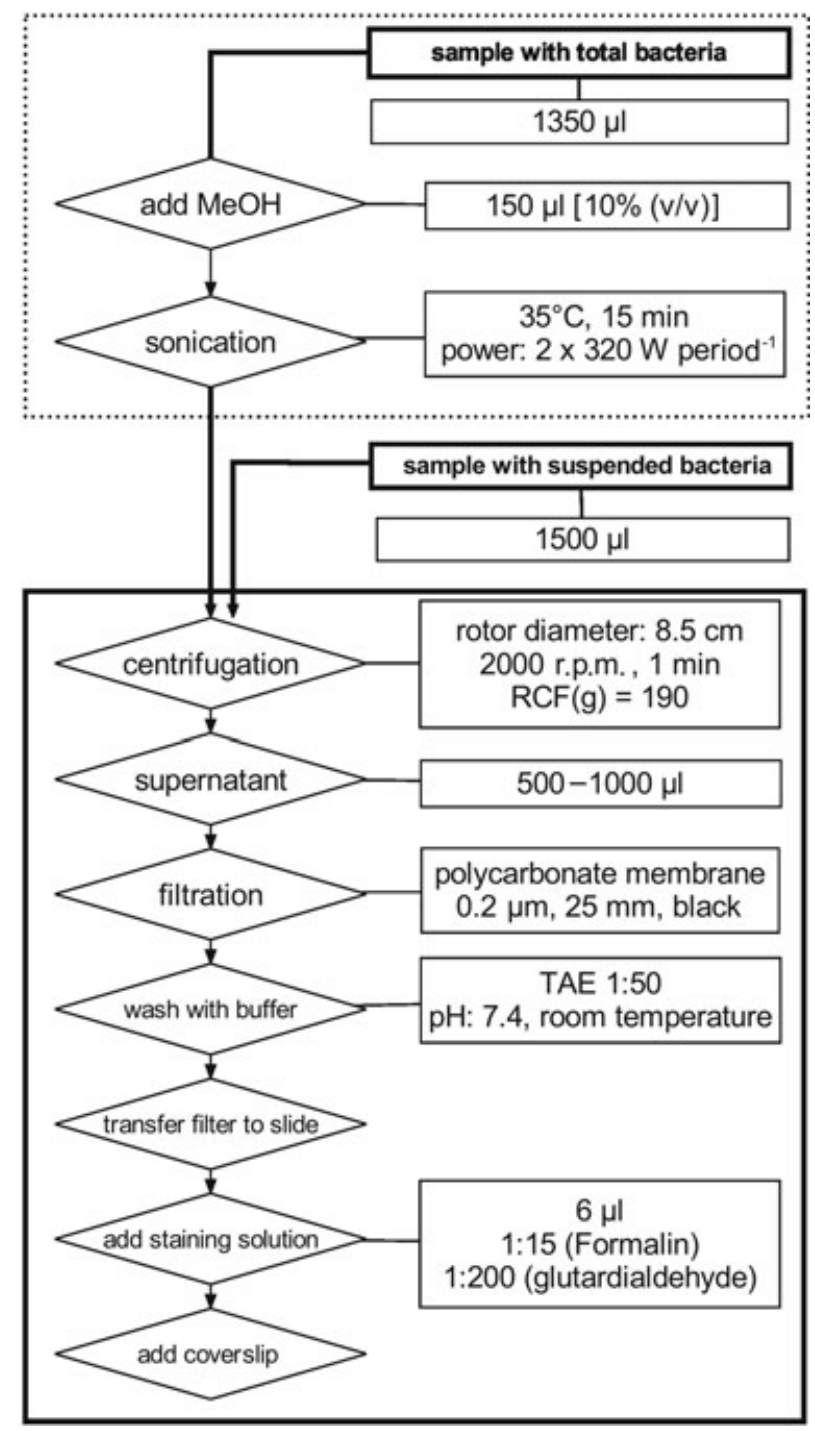

Fig. 1. Flow diagram of the new detachment and SybrGreen I staining method. The upper box (dotted line) outlines the sonication treatment and the lower box (solid lines) centrifugation and the staining and mounting procedure with moviol and SybrGreen I. 
Table 1. Location, date, depth, temperature, salinity and concentrations of suspended matter dry weight of the sampling stations.

\begin{tabular}{|c|c|c|c|c|c|c|c|c|}
\hline Location & Latitude N & Longitude E & Station & Date & $\begin{array}{l}\text { Depth } \\
\text { (m) }\end{array}$ & $\begin{array}{l}\text { Temperature } \\
\left({ }^{\circ} \mathrm{C}\right)\end{array}$ & $\begin{array}{l}\text { Salinity } \\
(\% / \%)\end{array}$ & $\begin{array}{l}\text { Dry weight } \\
\left(\mathrm{mg} \mathrm{l}^{-1}\right)\end{array}$ \\
\hline North Sea, German Bight & $54^{\circ} 29.82^{\prime}$ & $07^{\circ} 09.72^{\prime}$ & 1 & 1 April 2004 & 40 & 5.8 & 33.6 & 3.8 \\
\hline North Sea, German Bight & $54^{\circ} 13.57^{\prime}$ & $08^{\circ} 19.98^{\prime}$ & 2 & 2 April 2004 & 14 & 6.6 & 27.2 & 9.5 \\
\hline North Sea, German Bight & $53^{\circ} 52.79^{\prime}$ & $07^{\circ} 31.50^{\prime}$ & 3 & 2 April 2004 & 22 & 6.1 & 31.3 & 5.5 \\
\hline North Sea, Wadden Sea & $53^{\circ} 44.90^{\prime}$ & $07^{\circ} 40.00^{\prime}$ & 4 & 17 February 2003 & 8 & 0.9 & 29.4 & 35.8 \\
\hline North Sea, Wadden Sea & $53^{\circ} 44.90^{\prime}$ & $07^{\circ} 40.00^{\prime}$ & 5 & 27 August 2003 & 8 & 18.6 & 30.1 & 42.2 \\
\hline $\begin{array}{l}\text { North Sea, Wadden Sea, } \\
\text { sandy sediment }\end{array}$ & $53^{\circ} 44.49^{\prime}$ & $07^{\circ} 40.42^{\prime}$ & 6 & 5 June 2002 & 2 & nd & nd & nd \\
\hline Baltic Sea, muddy sediment & $57^{\circ} 18.00^{\prime}$ & $20^{\circ} 05.00^{\prime}$ & 7 & 12 June 2000 & 405 & 4.0 & 12.0 & nd \\
\hline
\end{tabular}

nd, not determined.

Table 2. Numbers of two bacterial strains (Ruegeria algicola, Gelidibacter algens) and of samples from the German Bight enumerated after staining with SybrGreen I, DAPI and acridine orange (AO) by epifluorescence microscopy.

\begin{tabular}{|c|c|c|c|c|c|}
\hline Sample & SybrGreen I & DAPI & $\mathrm{AO}$ & $P$ & Power \\
\hline Ruegeria algicola & $74.7 \pm 4.3$ & $72.6 \pm 5.9$ & $74.1 \pm 7.1$ & 0.39 & 0.05 \\
\hline Gelidibacter algens & $64.7 \pm 7.3$ & $64.6 \pm 5.9$ & $68.1 \pm 7.0$ & 0.07 & 0.34 \\
\hline German Bight, Station 1 & $46.0 \pm 2.9$ & $45.3 \pm 2.8$ & $45.3 \pm 2.7$ & 0.82 & 0.05 \\
\hline
\end{tabular}

Mean values \pm standard deviation of a microscopic view field $(n=20)$ are given. Comparison of the mean values was done by one way ANOVA $($ alpha $=0.5) . P$-values and the power are shown.

particles vortexing likely damaged the cells mechanically and resulted in lower numbers.

\section{Effect of detergents on detachment}

We compared the total number of cells after treatments with methanol, pyrophosphate and Tween-80 (Fig. 3, white bars) for two Wadden Sea samples with high amounts of SPM (stations 4 and 5). Furthermore, we estimated the error which is produced by attached cells lost by centrifugation of still intact aggregates after detergent treatment (Fig. 3, black bars). Therefore, $500 \mu \mathrm{l}$ of the supernatant (SN) was withdrawn after centrifugation and bacteria enumerated after SybrGreen I staining. Thereafter, the remaining sample $(\mathrm{R})$ was well mixed such that the pellet became re-suspended again, completely filtered and bacteria were enumerated the same way.

For the February sample the methanol treatment yielded similar bacterial numbers in both fractions, the

Table 3. One way ANOVA of bacterial numbers of a sample from the Wadden Sea (station 5, Table 1) stained by SybrGreen I, DAPI and acridine orange (AO), and enumerated by epifluorescence microscopy.

\begin{tabular}{lllll}
\hline Comparison & $\begin{array}{l}\text { Difference of } \\
\text { Means }\end{array}$ & q & $P$ & Power $<0.05$ \\
\hline $\begin{array}{c}\text { SybrGreen I } \\
\text { versus DAPI }\end{array}$ & 29.4 & 26.25 & $<0.001$ & Yes \\
$\begin{array}{c}\text { SybrGreen I } \\
\text { versus AO }\end{array}$ & 29.8 & 26.60 & $<0.001$ & Yes \\
\begin{tabular}{c} 
DAPI versus AO \\
\hline
\end{tabular} & 0.4 & 0.36 & 0.97 & No \\
\hline
\end{tabular}

supernatant and the remaining sample (one way ANOVA, Fig. 3A). In the August sample, bacterial numbers in the supernatant were $6 \%$ lower than in the remaining fraction, indicating that a minor proportion was not detached by this treatment (Fig. 3B). Both, in the pyrophosphate and Tween-80 treatments bacterial numbers in the supernatant were significantly lower than in the remaining fraction and in the supernatant of the methanol treatment (one way ANOVA, $P<0.01$ ). In addition, because of the uneven distribution of the aggregates with associated bacteria in the remaining fraction of the pyrophosphate and Tween80 treatments, there was a trend of overestimating bacterial numbers in those fraction of these samples. Further, the counting error was higher in these fractions than in the methanol-treated sample.

The application of the various detachment procedures to the samples of the stations listed in Table 1 showed that the methanol treatment resulted in the highest numbers of total bacteria and the highest percentage of particleassociated bacteria at all stations (Table 5). Percentages were 1.3- to >twofold higher than after treatments with

Table 4. Particulate organic matter (POC) as percent of SPM dry weight (DW), C/N-ratio and aggregate numbers of the February and August sample from the Wadden Sea.

\begin{tabular}{llll}
\hline Sample & POC/DW [\%] & C/N [by weight] & Aggregates $\left[\mathrm{ml}^{-1}\right]$ \\
\hline February 03 & 2.25 & 8.6 & 1038 \\
August 03 & 4.34 & 6.7 & 406 \\
\hline
\end{tabular}

$\mathrm{C} / \mathrm{N}$, carbon/nitrogen.

(C) 2005 Society for Applied Microbiology and Blackwell Publishing Ltd, Environmental Microbiology 


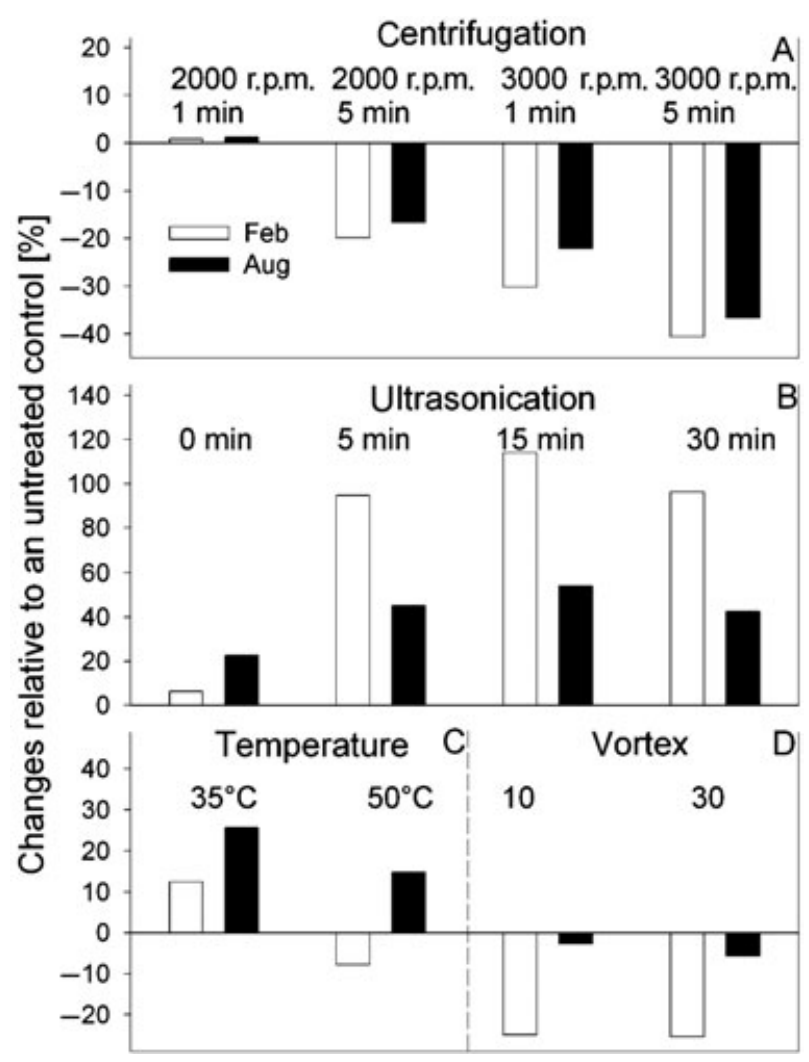

Fig. 2. The effects of centrifugation (A), sonication (B), temperature (C) and vortexing (D) on two methanol treated samples from the Wadden Sea collected in February and August 2003 (stations 4 and 5 , Table 1) on bacterial numbers. Bacteria were enumerated after the new staining and mounting procedure with moviol and SybrGreen I by epifluorescence microscopy.

pyrophosphate or Tween-80. The methanol treatment also resulted in much higher bacterial numbers of the two sediment samples.

This comparison showed that the detachment procedure with methanol leeds to higher numbers of cells than

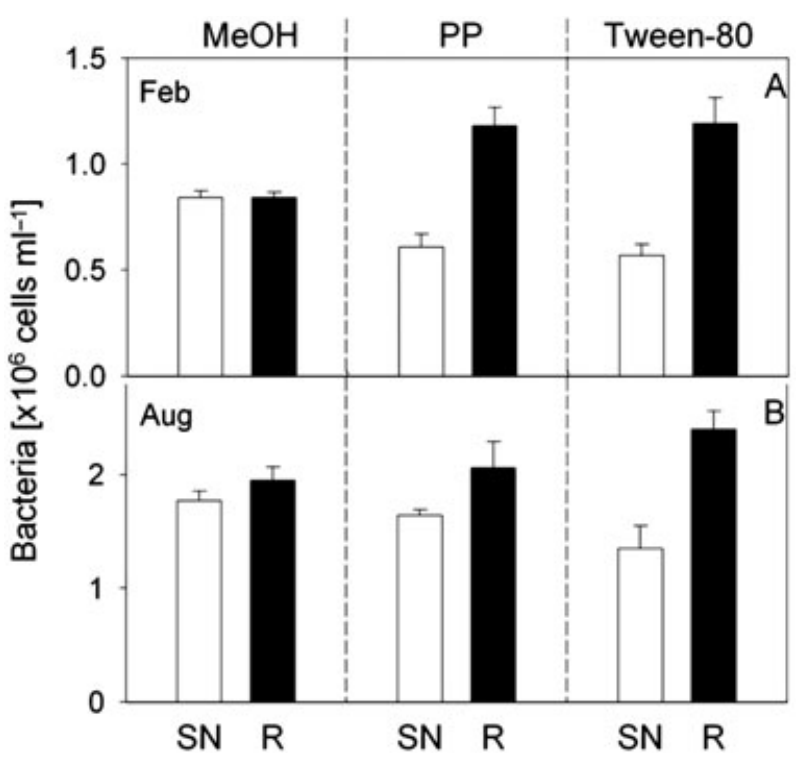

Fig. 3. Bacterial numbers in the supernatant (SN) and remaining fraction $(R)$, including the well resuspended pellet, of centrifuged samples from the Wadden Sea collected in February (A) and August 2003 (B) after treatment with methanol $(\mathrm{MeOH})$, pyrophosphate (PP) and Tween-80.

with pyrophosphate or Tween-80. The methanol treatment also resulted in a more even distribution of bacteria on the filter because more bacteria were detached and more bacteria-free particles were removed by centrifugation. A visual demonstration of the SybrGreen I-stained bacterial cells of an untreated sample from station 3 as compared to a centrifuged and methanol-treated sample is given in Fig. 4A-C. The untreated sample (Fig. 4A) exhibits a patchy and uneven distribution of the freely suspended cells and aggregates with associated cells. In contrast, the centrifugation of the sample largely removes aggregates and sediment particles with associated cells and enables a more accurate enumeration of the freely suspended bacteria (Fig. 4B). Filtration of only the supernatant led to

Table 5. Numbers ( \pm standard deviation) of free-living bacteria $(\mathrm{FL})$ and total bacteria after the detachment treatment with methanol $(\mathrm{MeOH})$, pyrophosphate, or Tween-80, and the percentage of particle-associated bacteria (PA) at the various locations and staining by SybrGreen I.

\begin{tabular}{|c|c|c|c|c|c|c|c|c|}
\hline \multirow[b]{2}{*}{ Location } & \multirow[b]{2}{*}{ Station } & \multirow[b]{2}{*}{$\begin{array}{l}\mathrm{FL} \\
10^{6} \mathrm{ml}^{-1}\end{array}$} & \multicolumn{2}{|c|}{$\mathrm{MeOH}$} & \multicolumn{2}{|c|}{ Pyrophosphate } & \multicolumn{2}{|c|}{ Tween 80} \\
\hline & & & $\begin{array}{l}\text { Total } \\
10^{6} \mathrm{ml}^{-1}\end{array}$ & $\begin{array}{l}\mathrm{PA} \\
\%\end{array}$ & $\begin{array}{l}\text { Total } \\
10^{6} \mathrm{ml}^{-1}\end{array}$ & $\begin{array}{l}\mathrm{PA} \\
\%\end{array}$ & $\begin{array}{l}\text { Total } \\
10^{6} \mathrm{ml}^{-1}\end{array}$ & $\begin{array}{l}\mathrm{PA} \\
\%\end{array}$ \\
\hline North Sea, German Bight & 1 & $0.51 \pm 0.03$ & $0.56 \pm 0.02$ & 7.6 & $0.53 \pm 0.05$ & 3.6 & $0.55 \pm 0.02$ & 6.0 \\
\hline North Sea, German Bight & 2 & $0.80 \pm 0.04$ & $1.03 \pm 0.05$ & 22.2 & $0.99 \pm 0.03$ & 19.1 & $0.96 \pm 0.03$ & 16.7 \\
\hline North Sea, German Bight & 3 & $1.15 \pm 0.05$ & $1.44 \pm 0.05$ & 19.9 & $1.25 \pm 0.05$ & 8.1 & $1.16 \pm 0.04$ & 0.4 \\
\hline North Sea, Wadden Sea & 4 & $0.44 \pm 0.03$ & $0.84 \pm 0.03$ & 47.4 & $0.61 \pm 0.06$ & 27.4 & $0.57 \pm 0.05$ & 22.1 \\
\hline North Sea, Wadden Sea & 5 & $1.39 \pm 0.07$ & $1.77 \pm 0.09$ & 21.6 & $1.64 \pm 0.05$ & 15.7 & $1.35 \pm 0.20$ & -2.6 \\
\hline $\begin{array}{l}\text { North Sea, Wadden Sea, } \\
\text { sandy sediment }\end{array}$ & 6 & - & $4.46 \pm 0.28^{a}$ & - & $3.64 \pm 0.28^{\mathrm{a}}$ & - & $2.56 \pm 0.27^{\mathrm{a}}$ & - \\
\hline Baltic Sea, muddy sediment & 7 & - & $903 \pm 0.01^{a}$ & - & $704 \pm 0.06^{a}$ & - & $577 \pm 0.08^{a}$ & - \\
\hline
\end{tabular}

a. $10^{6}$ (mg wet weight $)^{-1}$.

The number of particle-associated bacteria was calculated as the difference of bacteria counted in the total sample after centrifugation and the free-living bacteria in the untreated sample after centrifugation. 

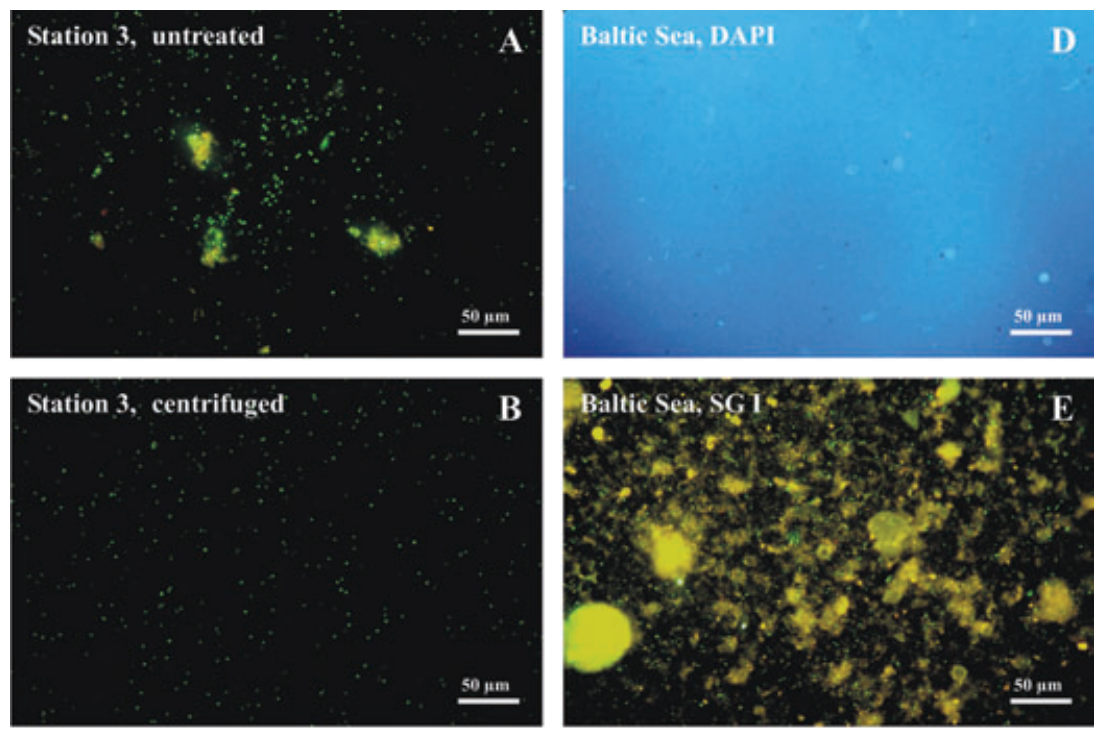

Fig. 4. Epifluorescence micrographs of bacteria detached from particles by the newly developed procedure with methanol and stained with DAPI and the moviol SybrGreen I staining and mounting medium.

A. Sample from the German Bight (station 3) stained by SybrGreen I not subjected to centrifugation.

B. The supernatant of the same sample without methanol treatment but subjected to centrifugation.

C. The remaining fraction of the same sample with methanol treatment and centrifugation.

Sediment sample from the Baltic Sea (station

7) stained by DAPI (D) and SybrGreen I (E).

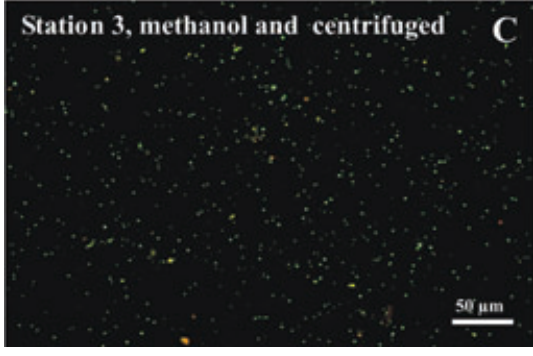

an even distribution of the suspended cells on the filter (Fig. 4B). The enumeration of the total number of cells is possible after methanol treatment which breaks most of the particles apart and sets free the associated bacteria (Fig. 4C). Thus, the number of cells increased in Fig. 4C as compared to Fig. 4B.

Figure 4E demonstrates that the methanol detachment procedure with subsequent centrifugation and the use of the described mounting medium with SybrGreen I is also well applicable to sediment-associated bacteria. It results in brightly fluorescent cells which are well recognizable on a low background fluorescence. In contrast, DAPI-staining (Fig. 4D) of the same sediment sample resulted in a high background fluorescence which makes it difficult to visualize and enumerate the bacteria.

\section{Fixation procedure and fluorescence yield}

In order to explore the minimum and optimum dilution of the SybrGreen I stock solution and whether the fixation has any affect on the fluorescence yield we stained Ruegeria algicola and Gelidibacter algens by different concentrations of a SybrGreen I dilution series from $1 \times 10^{-2}$ to $0.67 \times 10^{-5}$ after fixation with either glutardialdehyde or formalin ( $2 \%$ final concentration each) and determined the fluorescence yield in microplates. The results show that the fluorescence yield of the formalin-fixed bacteria was much lower than of the glutardialdehyde-fixed bacteria (Fig. 5), even at the lowest dilution of $1 \times 10^{-2}$. These results demonstrate that fixation by glutardialdehyde is highly superior over formalin regarding the signal intensity and that the former fixation procedure allows the staining by a highly diluted solution of SybrGreen I, thus leading to a cost-effective use of this attractive and highly dsDNAspecific fluorescent stain. Similar findings of the successful application of a highly diluted SybrGreen I solution for staining bacteria and viruses were reported by Noble and Fuhrman (1998).

\section{Conclusions}

Our tests and results show that the newly developed detachment procedure with methanol and staining and mounting with moviol-SybrGreen I yields accurate numbers of particle-associated bacteria in samples with varying amounts of SPM. The benefits of this method become in particularly clear in samples with high amounts of SPM such as highly turbid aquatic systems, e.g. tidal flats, estuaries and sediments. For detachment of bacteria from particles pyrophosphate and Tween-80 as detergent and sonication have been applied previously (Bakken, 1985; Velji and Albright, 1986; Yoon and Rosson, 1990; Buesing 
6 M. Lunau et al.

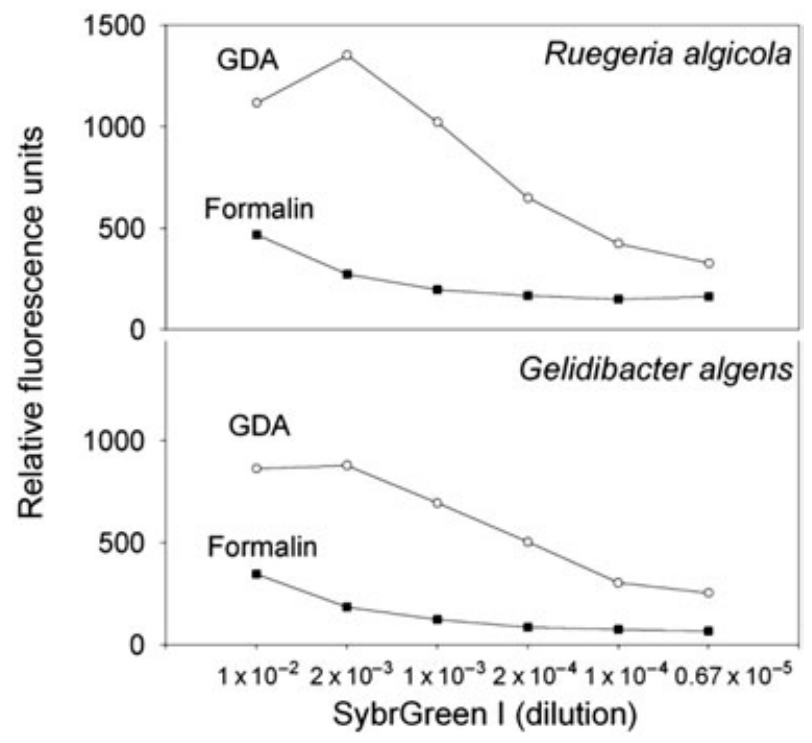

Fig. 5. Relative fluorescence yield of Ruegeria algicola and Gelidibacter algens stained by SybrGreen I of a dilution series after fixation with formalin and glutardialdehyde (GDA). Fluorescence was measured in the bacterial suspensions in microplates $1 \mathrm{~h}$ after fixation.

and Gessner, 2002). The comparison of our newly developed method showed that the sonication in $10 \%$ methanol at $35^{\circ} \mathrm{C}$ yielded significantly higher detachment efficiencies than the former detergents with quite different types of samples. We performed no comparison with an enzymatic detachment treatment (Böckelmann et al., 2003) and do not know whether the latter treatment yields similarly high proportions of detached bacteria. However, the application of our method appears less complicated and is more rapid than the enzymatic treatment.

SybrGreen I has been used previously to stain bacteria and viruses in samples from aquatic environments for epifluorescence microscopy (Noble and Fuhrman, 1998; Weinbauer et al., 1998; Danovaro et al., 2001) because of its high specificity for dsDNA and the low background fluorescence. One problem of applying this stain is the rapid fading. Introducing the described mounting procedure with buffered moviol and ascorbic acid as antioxidant and fixing the samples with glutardialdehyde, we were able to keep the bright fluorescence for several hours in samples stored at room temperature and even for several months in samples stored at $-20^{\circ} \mathrm{C}$. Hence, our newly developed staining and embedding procedure allows to prepare a batch of samples shortly after collection for later enumeration, expanding the application of SybrGreen I staining considerably. Hence, our staining procedure may also overcome the problem of bacterial losses in marine samples because of storing liquid samples (Turley and Hughes, 1992; Gundersen et al., 1996; Danovaro et al., 2001; Hyun and Yang, 2003; Wen et al., 2004).
The newly developed methanol detachment and SybrGreen I staining procedure appears to be well suitable for enumerating bacteria in samples with a high particle load and a high proportion of attached bacteria and appears to avoid disadvantages of other procedures. Because of the bright fluorescence and the avoidance of fading it also appears an attractive alternative to DAPIstaining and the application to bulk water samples with low amounts of SPM and particle-associated bacteria and without the methanol detachment. This method certainly will help to deepen our insight into growth dynamics of particle-associated bacteria in various aquatic environments.

\section{Experimental procedures}

\section{Sample collection and test organisms}

Surface samples from various stations of the German Bight of the North Sea and the Wadden Sea as well as sediment samples from the Wadden Sea and Baltic Sea were used for testing the detachment and SybrGreen I staining procedure (Table 1). The stations varied with salinity and exhibited pronounced differences in temperature and suspended matter dry weight. In addition, tests were performed with pure cultures of the $\alpha$-Proteobacterium $R$. algicola and the Flavobacterium Gelidibacter algens.

\section{Detachment with methanol and staining procedure with SybrGreen I}

The upper part of Fig. 1 (box with dotted line) shows a flow chart of the detachment procedure: In order to break up particles and detach bacteria $0.2 \mu \mathrm{m}$ filtered (Teflon filter, Sartorius, Germany) 100\% methanol (Rotisolv, Roth, Germany) was added to the sample at a final concentration of $10 \%$. Subsequently, the sample was incubated in a $1.5 \mathrm{ml}$ Eppendorf capped microcentrifuge tube (Eppendorf, Hamburg, Germany) for $15 \mathrm{~min}$ at $35^{\circ} \mathrm{C}$ in an ultrasonic bath (Bandelin, Sonorex RK $103 \mathrm{H}, 35 \mathrm{kHz}, 2 \times 320 \mathrm{~W}$ per period). At these conditions, methanol breaks up the exopolymeric substances, which are mainly composed of polysaccharides and entrap the surface-associated bacteria.

Samples were further processed as shown on the lower part of the flow chart on Fig. 1 (box with solid line). We treated all samples similarly, irrespective of whether the detachment procedure was applied or not. Samples subjected to the detachment procedure yield total bacterial numbers, including total and free-living cells, and samples without this procedure yield only free-living bacterial numbers. Samples were centrifuged for $1 \mathrm{~min}$ at 2000 r.p.m. (relative centrifugal force: $190 \mathrm{~g}$, Heraeus Biofuge pico, rotor diameter $8.5 \mathrm{~cm}$ ) to remove detrital and inorganic particles. Five hundred to $1000 \mu \mathrm{l}$ of the supernatant were filtered through a black $0.2 \mu \mathrm{m}$ polycarbonate filter (Nuclepore or Poretrics, $25 \mathrm{~mm}$ diameter, shiny side up) and stained as described below. Sediment samples were treated in the same way but the supernatant was diluted 1:100 with TAE buffer before filtration. 
The filter was washed $3 \mathrm{x}$ with $1 \mathrm{ml}$ of TAE buffer and transferred to a microscope slide. Six microlitres of the SybrGreen I staining and mounting medium (see below) were placed in the middle of a cover slip $(18 \mathrm{~mm} \times 18 \mathrm{~mm})$, which was then put upside down on the filter. Finally, the cover slip was pressed carefully onto the slide by tweezers to dispense the staining solution equally over the filter. It is also possible to add the solution directly onto the filter before adding the cover slip, but the distribution of the solution is less accurate and sometimes the filter turns yellowish thus leading to problems in the microscopic inspection. The amount of staining solution may need to be varied if a different sized cover slip is used. The procedure was optimized for black polycarbonate and aluminum oxide filters (Anodisc, Whatman). For other filter types it may be necessary to change the viscosity of the staining solution by varying the amount of buffer in the mounting medium.

Bacteria can be inspected by epifluorescence microscopy immediately, but we prefer to wait for at least 15-30 min before counting to allow an equal dispersion of the mounting medium under the cover slip. Staining is fine for several hours if slides are kept at room temperature. Storage at $-20^{\circ} \mathrm{C}$ keeps a bright fluorescence signal for at least several months.

\section{Detachment with pyrophosphate and Tween-80}

To compare our results with established detachment procedures we also applied sodium pyrophosphate (Acros Organics, $10 \mu \mathrm{M}$ final concentration; Velji and Albright, 1986) and Tween-80 (Fluka, 0.1\% final concentration; Yoon and Rosson, 1990).

\section{$D A P I$ and acridine orange staining}

One hundred microlitres of the DAPI stock solution $(1 \mathrm{mg}$ $\mathrm{ml}^{-1}$ ) were added to $1 \mathrm{ml}$ of sample which was stained for 8$10 \mathrm{~min}$ and then filtered through a black $0.2 \mu \mathrm{m}$ Nuclepore filter. For staining with acridine orange $40 \mu \mathrm{l}$ of stock solution (0.5 mg ml${ }^{-1}$, dissolved in PBS) were added to $1 \mathrm{ml}$ of sample, stained for $2 \mathrm{~min}$ and further treated as the DAPI-stained sample. Filters were mounted with pure moviol without SybrGreen I before the cover slip was placed on top.

\section{Preparation of the mounting medium}

The mounting medium was prepared in $25 \mathrm{ml}$ polypropylene tubes following the improved protocol of House Ear Institute (http://www.hei.org/research/depts/aemi/moviol.htm): $2.4 \mathrm{~g}$ of polyvinylalcohol 4-88 (moviol 4-88, Fluka, Switzerland) were added to $6 \mathrm{~g}$ of glycerol (for fluorescence microscopy, Merck) and vigorously mixed at room temperature for $30 \mathrm{~min}$. Moviol did not dissolve completely. Thereafter, $6 \mathrm{ml}$ of double-distilled water was added and the solution was stirred for two more hours. Some of the moviol still remained undissolved. The addition of $14 \mathrm{ml}$ of TAE (1x, pH 7.4, Eppendorf, Hamburg) and mixing for another $2 \mathrm{~h}$ at $50^{\circ} \mathrm{C}$ dissolved moviol completely and turned the solution clear. Finally, the solution was filtered through a $0.2 \mu \mathrm{m}$ Nalgene filter and aliquots of 200-1000 $\mu \mathrm{l}$ were stored frozen at $-20^{\circ} \mathrm{C}$.

\section{Preparation of the staining solution}

We subdivided the concentrated SybrGreen I stock solution (Molecular Probes, Eugene, OR, USA) into small aliquots directly upon arrival because repeated thaw and freeze causes rapid decrease in fluorescence intensity. To achieve optimal fluorescence signals, the SybrGreen I stock solution was diluted differently by moviol for samples fixed by formalin, glutardialdehyde or for unfixed samples. For formalin-fixed samples (2-4\% final concentration) a dilution of more than $1: 15\left(6.7 \times 10^{-2}\right)$ resulted in a substantially reduced fluorescence intensity of the stained cells whereas for glutardialdehyde ( $2 \%$ final concentration) or unfixed samples a dilution of $1: 50\left(2 \times 10^{-2}\right)$ up to $1: 200\left(5 \times 10^{-3}\right)$ still resulted in brilliantly fluorescing cells. We added the SybrGreen I stock solution to the mounting medium in small PCR soft tubes (0.2 ml, Biozym, Oldendorf, Germany) and vortexed it. A freshly prepared $1 \mathrm{M}$ ascorbic acid solution, dissolved in TAE buffer ( $\mathrm{pH} 7.4$, Sigma) was added at a final concentration of $1 \%$ as an antioxidant. We preferred the use of ascorbic acid instead of phenylenediamine (Noble and Fuhrman, 1998) because it turns out to work properly and is not toxic. Because the $\mathrm{pH}$ of the buffer is temperature-sensitive and increases by approx. $+0.5 \mathrm{pH}$ units, while cooling from room temperature to $4^{\circ} \mathrm{C}$ all reagents have to be adjusted to $\mathrm{pH} 7.4$ at room temperature very carefully before storing at $4^{\circ} \mathrm{C}$. Otherwise the $\mathrm{pH}$ may rise to $>8$ thus damaging the fluorescent stain. As an alternative PBS may be used. It has a higher buffering capacity and is less temperature-affected than TAE. The staining solution can be kept at $4^{\circ} \mathrm{C}$ for several weeks. It should not be stored frozen (see useful tips at http:// www.probes.com).

\section{Nucleic acid staining of bacterial strains for fluorescence reading in microplates}

The Sybr Green I stock solution was diluted $1 \times 10^{2}-$ $1.5 \times 10^{4}$-fold with Tris-HCl/EDTA buffer (200 mM Tris, $50 \mathrm{mM}$ EDTA). Cells were preserved $1 \mathrm{~h}$ with formalin- or glutardialdehyde ( $2 \%$ final concentration) before analysis. For analysis $200 \mu \mathrm{l}$ of a R. algicola culture $\left(1.8 \times 10^{6}\right.$ cell $\left.\mathrm{ml}^{-1}\right)$ or G. algens culture $\left(0.8 \times 10^{6} \mathrm{cell} \mathrm{m}^{-1}\right)$ were dispensed into black 96-well microplates (Fluoronunc F96, Nunc GmbH, Wiesbaden, Germany). The fixed cultures were subsequently stained by $50 \mu \mathrm{l}$ of the diluted dye. Fluorescence intensity was determined in a microplate reader (Fluorostar Optima, BMG Labtechnologies, Offenburg, Germany) at 485/520 nm directly after adding the dye. All measurements were carried out in three reading cycles with integration of 20 flashes and $0.5 \mathrm{~s}$ delay between plate movement and readings.

\section{Cell counts}

Cells were counted with a Zeiss Axiolab microscope at $1000 \times$ magnification (lamp: HBO 50, filter set: Zeiss, Ex 450-490, FT 510, LP 515). The filtration volume of $500 \mu \mathrm{l}$ yielded 20 60 stained cells in the counting grid $(125 \times 125 \mu \mathrm{m})$. A minimum of 400 cells (10-20 view fields) were enumerated. The number of free-living bacteria was determined directly in samples not subjected to the detachment procedure and the 


\section{M. Lunau et al.}

number of particle-associated bacteria was calculated as the difference of the number of total bacteria in the corresponding samples with and without detachment.

\section{Acknowledgements}

We would like to thank B. Rink for providing the two bacterial strains. This work was supported by the Deutsche Forschungsgemeinschaft within the Research Group 'BioGeoChemistry of the Wadden Sea' (FG 432, TP 5).

\section{References}

Bakken, L.R. (1985) Separation and purification of bacteria from soil. Appl Environ Microbiol 49: 1482-1487.

Bergström, I., Heinanen, A., and Salonen, K. (1986) Comparison of acridine orange, acriflavine, and bisbenzimide stains for enumeration of bacteria in clear and humic waters. Appl Environ Microbiol 51: 664-667.

Böckelmann, U., Szewzyk, U., and Grohmann, E. (2003) A new enzymatic method for the detachment of particle associated soil bacteria. J Microbiol Meth 55: 201-211.

Buesing, N., and Gessner, M.O. (2002) Comparison of detachment procedures for direct counts of bacteria associated with sediment particles, plant litter and epiphytic biofilms. Aquat Microb Ecol 27: 29-36.

Crump, B.C., Baross, J.A., and Simenstad, C.A. (1998) Dominance of particle-attached bacteria in the Columbia River estuary, USA. Aquat Microb Ecol 14: 7-18.

Danovaro, R., Dellánno, A., Trucco, A., Serresi, M., and Vanucci, S. (2001) Determination of virus abundance in marine sediments. Appl Environ Microbiol 67: 1384-1387.

Gundersen, K., Bratbak, G., and Heldal, M. (1996) Factors influencing the loss of bacteria in preserved seawater samples. Mar Ecol Prog Ser 137: 305-310.

Hobbie, J.E., Daley, R.J., and Jasper, S. (1977) Use of Nuclepore filters for counting bacteria by fluorescence microscopy. Appl Environ Microbiol 33: 1225-1228.

Hyun, J.H., and Yang, E.J. (2003) Freezing seawater for the long-term storage of bacterial cells for microscopic enumeration. J Microbiol 41: 262-265.
Kepner, R.L., and Pratt, J.R. (1994) Use of fluorochromes for direct enumeration of total bacteria in environmental samples: past and present. Microbiol Rev 58: 603-615.

Noble, R.T., and Fuhrman, J.A. (1998) Use of SYBR Green I for rapid epifluorescence counts of marine viruses and bacteria. Aquat Microb Ecol 14: 113-118.

Porter, K.G., and Feig, Y.S. (1980) The use of DAPI for identifying and counting aquatic microflora. Limnol Oceanogr 25: 943-948.

Singer, V.L., Lawlor, T.E., and Yue, S. (1999) Comparison of SYBR (R) Green I nucleic acid gel stain mutagenicity and ethidium bromide mutagenicity in the Salmonella/mammalian microsome reverse mutation assay (Ames test). Mutat Res-Gen Tox En 439: 37-47.

Turley, C.M., and Hughes, D.J. (1992) Effects of storage on direct estimates of bacterial numbers of preserved seawater samples. Deep-Sea Res I (39): 375-394.

Velji, M.I., and Albright, L.J. (1986) Microscopic enumeration of attached marine bacteria of seawater, marine sediment, fecal matter, and kelp blade samples following pyrophosphate and ultrasound treatments. Can J Microbio/ 32: 121126.

Weinbauer, M.G., Beckmann, C., and Höfle, M.G. (1998) Utility of green fluorescent nucleic acid dyes and aluminium oxide membrane filters for rapid epifluorescence enumeration of soil and sediment bacteria. Appl Environ Microbiol 64: 5000-5003.

Wen, K., Ortmannn, A.C., and Suttle, C. (2004) Accurate estimation of viral abundance by epifluorescence microscopy. Appl Environ Microbiol 70: 3862-3867).

Wilson, W.D., Tanious, F.A., Barton, H.J., Jones, R.L., Fox, K., Wydra, R.L., and Strekowski, L. (1990) DNA sequence dependent binding modes of 4',6-diamidino-2-phenylindole (DAPI). Biochemistry 29: 8452-8461.

Yoon, W.B., and Rosson, R.A. (1990) Improved method of enumeration of attached bacteria for study of fluctuation in the abundance of attached and free-living bacteria in response to diel variation in seawater turbidity. Appl Environ Microbiol 56: 595-600.

Zimmermann, R., and Meyer-Reil, L.A. (1974) A new method for fluorescence staining of bacterial populations on membrane filters. Kiel Meeresforsch 30: 24-27. 